\title{
Brød i behandlingen av epilepsi
}

| 1930-årene forsøkte man å behandle epilepsi med brød som var tilsatt bromnatrium. Nevrologen G.H. Monrad-Krohn (1884-1964) beskrev et slikt forsøk fra Statens pleiehjem for epileptikere, der han var tilsynslege (Tidsskr Nor Lægeforen 1939; 59: 1075-85). Resultatene på anfallsfrekvens var blandet, men behandlingen så ut til å ha alvorlige konsekvenser: Mange av pasientene ble «meget mer krakilske og vanskelige», og Monrad-Krohn bemerket at i 1939 var det ni dødsfall av interkurrente sykdommer, mens det i de tre foregående kalenderår kun hadde vært to dødsfall per år.

\section{Behandling med Bromnatriumbrød («Epileptikerbrød»).}

Erfaringer fra Statens pleiehjem for epileptikere.

\author{
Av G. H. Monrad-Krohn, Oslo
}

Da der i «Tidsskrift for Den norske lægeforening» $\mathrm{i}$ løpet av de senere år fra lægehold var kommet lovende beregninger om behandling av epilepsi med «epileptikerbrød» (bromnatriumbrød), og da der også var fremkommet en rekke henstillinger fra patientenes pårørende om å forsøke dette så sterkt roste brød, besluttet jeg efter konferanse med avdøde medisinaldirektør Heitmann ${ }^{1}$ å forsøke denne behandling i mere utstrakt skala i Statens pleiehjem for epileptikere.

Den 1. desember 1937 begynte denne behandling hos 60 patienter. (Hele anstalten har bare 68 patienter). Medikasjonen er blitt gjennemført efter følgende opskrift, hentet fra Stengels opsats:

$1 / 4 \mathrm{~kg}$. hvetemel og $1 / 4 \mathrm{~kg}$. hvetegrøp tilsettes $30 \mathrm{~g}$. bromnatrium, gjær og vann. Skal ikke saltes. Herav eltes en deig som settes til gjæring. Av deigen bakes et brød som skal spises op på 7 dager, nøiaktig like meget morgen og aften, altså $1 / 14$ av brødets vekt morgen og aften. Spises som almindelig smørbrød med eller uten pålegg.

Når appetitten har vært stor, har man tillatt patienten å spise litt almindelig brød i tillegg, N.B. efter at bromnatriumbrød-rasjonen først var blitt fortært.

Da de fleste patientene tidligere hadde fătt sovinal i en eller annen form, og da det også dreiet sig om tilfelle med stor anfallsfrekvens, fant jeg det for de flestes vedkommende riktigst å gi en liten dose sovinal i tillegg ( 0,05 sovinal vespere) for å undgå den fare for status som ofte opstår ved komplett ophør av sovinalmedikasjon. [...]

Som det fremgår av foregående har bromnatriumbrødbehandlingen en anfallsforebyggende virkning, som i enkelte tilfelle overgår den virkning som vår vanlige kombinerte sovinal-brombor-behandling har. I andre tilfelle er bromnatriumbrødbehandlingen denne underlegen. [...]

Konklusjonen på disse forsøk må bli at bromnatriumbrødbehandlingen er en terapi som kan forsøkes i enkelte tilfelle hvor andre midler har sviktet. Men behandlingen fordrer at patientens almentilstand må kontrolleres i enn høiere grad enn ved annen behandling.

${ }^{1}$ Nils Peter Løberg Heitmann (1874-1938), lege og medisinaldirektør (1931-38) 